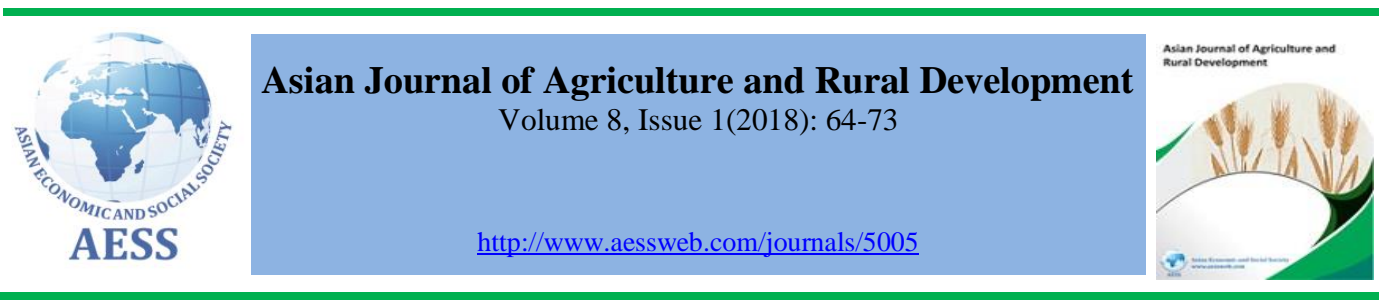

\title{
THE ECONOMIC IMPACT OF STALL FEEDING ON COW MILK PRODUCTION AND CALF DEATH: EMPIRICAL EVIDENCE FROM NORTHERN ETHIOPIA
}

(D) Muuz Hadush a a Lecturer; Department of Economics, Mekelle University, Tigrai, Ethiopia \& Ph.D. student; Norwegian

D Berhe Gebregewergs University of Life Science(NMBU), Norway Hagos $^{b}$

$\downarrow \square$ muuz.hadush@mu.edu.et (Corresponding Author)

${ }^{\mathrm{b}}$ Department of Economics, Mekelle University, Tigrai, Ethiopia

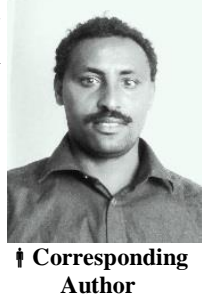

\section{ARTICLE HISTORY:}

Received: 28-Aug-2018

Accepted: $16-$-Oct- 2018

Online Available: $31-$-Oct2018

\section{Keywords:}

Cow Milk,

Calf Death,

IV 2SLS,

Stall Feeding,

Tigrai,

Ethiopia

\begin{abstract}
Ethiopia, the emerging economies of Africa has abundant cow milk potential but its milk harvest is negligible. In order to enhance milk yield, an improved livestock feeding practice such as stall feeding (SF) is introduced and expanded in the region. In this paper, we aim to evaluate the impact of stall feeding on rural farmers' milk production and calf death using IV 2SLS model. The paper used a primary data collected from 251 randomly selected smallholder households consisting 115 adopters and 136 non-adopters. Accordingly, the average SF adopter's milk production per day per cow is 1.3 litters larger as compared to the non-users. Likewise, Stall feeding significantly reduces the probability of death for the newly born calves by about $68 \%$.
\end{abstract}

\section{Contribution/ Originality}

This paper distinguishes itself from the past related research works in two ways: Firstly, this study is perhaps the first to show how stall feeding users compared to non-users benefit from it, using proper impact evaluation design compared to prior survey studies which totally neglected the endogeneity problem. Secondly, the adoption of stall feeding is slow, probably due to a lack of understanding of its positive impact. Being able to precisely estimate its impact would influence the possible types of policies to be implemented in order to expand its coverage.

DOI: 10.18488/journal.1005/2018.8.1/1005.1.64.73

ISSN (P): 2304-1455/ISSN (E):2224-4433

How to cite: Muuz Hadush and Berhe Gebregewergs Hagos (2018). The economic impact of stall feeding on cow milk production and calf death: empirical evidence from Northern Ethiopia. Asian Journal of Agriculture and Rural Development, 8(1), 64-73.

(C) 2018 Asian Economic and Social Society. All rights reserved. 


\section{INTRODUCTION}

Ethiopia is one of the milk production potential emerging economies around the globe including Brazil, China, India, and Pakistan (FAO, 2018). Livestock as part of the agriculture economic sector alone contributes about 47\% yield to this sector in Ethiopia (cited in Behnke and Metaferia, 2011). Factors such as climate variability, low-quality feed, lower management, low genetic potential for milk production, and high incidence of disease resulted lower milk yields and shorter lactations in developing countries including Ethiopia (FAO, 2018; Ngeno, 2018; Ojango et al., 2016; Adane et al., 2015; Tegegne et al., 2013).

Stall feeding improves milk productivity and economic livelihood of smallholder farmers in Kenya (Kipkoech, 2014). Similarly, stall feeding adopter households' income in Uganda has increased from the sales of cow dung manure and average crop outputs reaches \$US 1,041 per annum as compared to non-adopter households' whose crop outputs value is \$US340 (Zimbe, 2012). Dairy milk consumption for households who have adopted stall feeding accounts for 0.39 litters against to the non-adopters of 0.11 litters (Zimbe, 2012). Declining grazing land, low market for cash crops, low yield of local cattle, declining soil fertility and low income, cheap price for local cattle and products, and disease challenges under free grazing are the main expected causes to raise adoption of stall feeding on small-scale farmers today in the world (cited in Nalunkuuma et al., 2013). Nonetheless, in Germany, open grazing benefits more in terms of ecological and economic perspectives against the zero grazing adopter farmers (Meul et al., 2012).

Although Ethiopia owns large livestock from Africa, the dairy farming productivity is low even compared to its neighbouring countries (Adane et al., 2015; Tegegne et al., 2013; cited in De Cao et al., 2013). The total cattle holding of households in Ethiopia ranges from two to four, of which $25 \%$ are used for a dairy purpose which is below standard (Negassa et al., 2012). Irrespective of the diverse livestock, good agro-ecology, high demand for dairy products, the culture of societal dairy consumption, and supportive government policy in Ethiopia, productivity of dairy animals is limited (Tegegne et al., 2013). Ethiopian most small-scale dairy farmers produce 1.5 litters per day per cow from their indigenous, which is 20 folds far lower than the milk production level of developed countries today (Stapleton, 2018). Moreover, the mean milk production level in Mekelle, Tigrai, Ethiopia is about $730 \mathrm{~kg}$ per cow per year unlike to $1829 \mathrm{~kg}$ per cow per year in the peri-urban farms though still lower than what is produced in our next-door country Kenya (Woldegebriel et al., 2017). However, the cross breed dairy cows' productivity in some urban Ethiopia reached 10.21 to 15.9 liters per cow per day that outsmarts the peri-urban 9.5 litters (Tegegne et al., 2013).

A research made in Tanzania, Kenya, India, and Nigeria has proven that enhanced and quality use of breeding, reproductive technologies, and infrastructure are the factors that enhance milk yield per cow per day (Ojango et al., 2016). Education, experience, and size of the farmland positively contributed to the efficient milk production in Kenya smallholder farms (Nganga et al., 2010). However, the age of the smallholders impacted negatively. Land size, access to extension services, infrastructure, and level of education reduce the efficiency of milk producers in Kenya (Majiwa et al., 2010). Benefit, awareness, the source of finance, the source of credit, land tenure, and disease outbreaks variables have no effects of zero grazing on dairy farmers (Kipkoech, 2014).

Nalunkuuma (2013) revealed that gender (male), herd size, number of family members going to school, and the number of small ruminants negatively impacted of zero grazing adoption in western Kenya. Age, education, number of exotic cattle, above poverty ratio (Ksh 2,500), dependency ratio, and number of cross breed cattle affect for zero grazing positively (Ibid). On the other hand, age, off-farm income, and training were affecting negatively the milk production through $50-70 \%$ of rural Bangladesh's economy relied on (Sultana et al., 2016). Farmers' knowledge of cattle reproductive parameters, number of exotic cattle, number of cross breed cattle, milk production as the most important reason for keeping cattle, being above the poverty line of $(\mathrm{Ksh} 2,500)$, and zero 
grazing impacted milk production positively (Nalunkuuma, 2013). But, gender (male), herd size, ownership of means of transport and the number of ruminants impacted negatively to milk production in western Kenya (Ibid).

Furthermore, a research made in four regional states of Ethiopia disclosed that lactating cows, crossbred cow, agro-ecological zone, labor supply, supplementary feed purchase, education, wealth, and access to market affected milk production negatively (Adane et al., 2015). Nevertheless, size of grazing land, amount of crop residue, cost of purchased feed, health expenditure, distance to Woreda, distance to development agent's (DA), sex, and age has a neutral effect on the milk production (Adane et al., 2015). Education, extension services, credit access, landholding, and herd size positively impacted the households participated in the dairy hubs welfare Kenya (Ngeno, 2018). However, variables distance to the dairy hub, off-farm activities, and size of households determines negatively for the welfare of the non-participants welfare. Small-scale farm households participated in the dairy hubs average milk production per cow per day reached 6.17 litters as compared to the non-participants which they produce 4.67 litters (Ngeno, 2018). Likewise, dairy hub participant smallholder farmers' net profit outweighs their counters by more than $45 \%$. As shown above, large prior researchers did not agree on the returns of adoption of stall feeding and determinants of milk production by small-scale households' This is then the driving factor for this research.

Stall feeding is a recent episode in the study area and envisions evaluating its impact. The study is designed to answer the following lists of research questions; (1) what exactly is the impact of stall feeding adoption on milk harvest and calf death? What factors other than stall feeding affect milk production and probability new born calf death? We answered these questions using instrumental variable (IV 2SLS) estimation method in order to account for endogeneity problem.

\section{MATERIALS AND METHODS}

\subsection{Data type}

A cross-sectional data from was collected from Tahtay Maichew district composed of owns 19 subdistricts $\left(\mathrm{Tabia}^{1}\right)$ which is one of the leading districts to implement stall feeding in Tigrai, was purposively selected putting its experience in stall feeding and ecological similarities with the other districts in to account. Of the total Tabias, eight Tabias have found to start stall feeding in 2005 (BoFED, 2010). This survey is based on a three-stage stratified sample design. In the first stage, three stalls feeding adopter Tabias out of eight were selected. In the second stage, three stall feeding users and three comparable control villages ${ }^{1}$ were randomly selected using similar geographical, ecological and socio-economic indicators. In the last, a list of household heads for each village was supplied by respective Tabia leaders and 115 stall feeding adopters and 136 non-adopters were chosen using random sampling techniques. Every household head was given equal chance of being included without bias.

Table 1: Sample size of households per village

\begin{tabular}{lcccccc}
\hline Region & Zone & District & Tabia & Village & Category & Sample \\
\hline & & & & Adieyo(ae) & Treated & 35 \\
& & & Kewanit & Menqeraqho(mn) & Treated & 36 \\
\multirow{2}{*}{ Tigrai } & Central & \multirow{2}{*}{ TahtaiMaichew } & & Laelaykewanit(lkw) & Controlled & 46 \\
& zone & & Hadushadi & Amoke(am) & Controlled & 45 \\
& & & \multirow{2}{*}{ Akab seat } & Hadushadi(ha) & Controlled & 45 \\
& & & & Guada(gau) & Treated & 44 \\
Total & & & & & 251 \\
\hline
\end{tabular}

Source: Own survey, 2016

${ }^{1}$ Village (Kushet) is the smallest governance system (next to Tabia) in Ethiopia 


\subsection{Econometrics model}

Descriptive statistics give only a mere first indication of the impact of SF. First, users in this study might belong to the more advantaged groups in terms of access to irrigation and market given th a these groups are also more likely to have high milk yield outcomes without the intervention, controlling household characteristics in order not to overestimate the impact of the treatment is required. Moreover, since participation is a voluntary decision, this could lead to as selection bias. Users might differ on additional unobservable characteristics such as awareness or motivation that could have a direct effect on the outcomes beyond participation in the SF.

Thus, the econometric model used to evaluate the impact of stall feeding on milk production and calf death is an IV 2SLS estimation specified as below:

$$
Y_{i}=\alpha+\beta_{i} X_{i}+\gamma D_{i}+\eta_{i} \ldots \ldots \ldots \ldots \ldots \ldots \ldots \ldots \ldots \text { (1) }
$$

Where; $Y_{i}=1$ the mean value of milk harvest (production) in litter per cow per day and calf death which is binary ( $1=$ for calf died below 1 year, $0=$ for calf survived above)

$X_{i}=$ a vector of exogenous explanatory variables like(cow type, cow age, breed residue, food share, calf milk, water distance, summer, autumn, and spring seasons, calf sex, households sex, age, family size, education, herd size, market distance, extension distance, and so forth) $D_{i}=1$ if a household member iparticipates in the intervention (i.e., stall feeding) and 0 otherwise. The estimate for $\gamma$ captures the treatment effect for participants in the policy group compared to the control group.

Estimating the above model does not give the true treatment effect since farmers themselves decide whether to adopt SF. The assignment is by self-selection or participation, in this case, is endogenous due to two reasons: selection bias due to unobserved household characteristics and omitted variable bias (households' talent, motivation, ability, awareness and level of information). The difference between SF adopters and non-adopters is likely to be systematic. Treating $D_{i}$ as an exogenous variable and applying OLS would result in inconsistent parameter estimate. To account for participation selection bias, instruments for the decision to become participants is used. A two-stage (2SLS) instrumental variables approach with probit model for binary outcomes in both stages and probit model in first stages and linear OLS/LPM or Tobit model in the second stage for continuous outcomes were used. The first stage model reflects the participation decision (hereafter reduced equation) and has the form:

$$
D_{i}=C+\lambda X_{i}+\delta Z_{i}+\mu_{i}
$$

Where; $X_{i}=$ Encompasses exogenous household's and village characteristics $Z_{i}=$ Contains the instruments not included in $X_{i}$.

This equation is estimated to predict the probability of participation for the entire households. The predicted participation variable $D_{i}$ is then reentered as a new exogenous variable in the outcome equation as under:

$$
Y_{i}=\alpha+\beta_{i} X_{i}+\gamma \widehat{D}_{i}+\eta_{i}
$$

Analysis of the treatment effects estimated using the above specification. In the absence of participation treatment heterogeneity; the estimate for $\gamma$, reflects the average treatment effect of participation (Blundell and Monica, 2000; Heckman, 1997). To correct for the potential participation selection bias, instrumental variables that are correlated with participation but not correlated with the outcomes of the treatment (and is thus not correlated with the result and error term in the outcome equation) are required. Mechanically, the IV method is no more difficult than OLS regression method to implement but it is more difficult than other methods conceptually. Although it is usually a difficult, it's easily done as follows. 
In this estimation, the estimation used three instrumental variables named school distance measured in walking minutes for students, membership of Tabia council (binary) and the ratio of grazing land to the total area of the village (hectare). Distance to school is supposed to have a negative effect on participation in SF. Longer distance to school was supposed to discourage household to educate their child, suggesting that they prefer their children to stay outside the school and not to feed their animal under SF if the child is available for looking after these animals in the free grazing system. Council membership is supposed to have positive impact on participation because a member has high information and awareness about the benefit of SF than non-members. Farmers living in villages of lower grazing ratio are supposed to be high participants than farmers living in the village of high grazing ratio proposing grazing ratio to be a good instrument for participation in stall feeding.

\section{RESULTS AND DISCUSSION}

\subsection{Descriptive analysis}

From table 2, milk harvest and calf death are compared by participation in panel 'A' using T-test and by each village in panel ' $\mathrm{B}$ ' with F-test. Cows in a stall feeding village appear to have an average of 2.4litters more as compared to cows in the non-adopter villages given that it is statistically significant at p-value of (<.05) for 5\% level of significance and lower mean calf death $(28 \%)$ than untreated cows (72\%). However, the difference is not significant enough to conclude that SF reduces calf death at p-value of 0.1456 using simple mean comparison. Furthermore, breed cows give 1.2 litters more than local cows (indigenous) regardless of their treatment which is significantly different.

Table 2: Comparison of stall feeding adopters and non-adopters by outcome variables

\begin{tabular}{|c|c|c|c|c|c|c|c|c|c|c|c|c|c|c|c|c|c|}
\hline \multirow[t]{2}{*}{ Variable } & \multicolumn{8}{|c|}{ Control } & \multicolumn{7}{|c|}{ Adopters } & \multirow{2}{*}{\multicolumn{2}{|c|}{$\operatorname{Pv}(\mathrm{T})$}} \\
\hline & Obs & mean & & SD & & Min & $\mathrm{Ma}$ & & Obs & me & an & SD & Min & & Max & & \\
\hline \multicolumn{18}{|l|}{ Panel A } \\
\hline \multicolumn{18}{|l|}{ Milk } \\
\hline Milk harst & 89 & 1.449 & & 0.6949 & & 1 & 4 & & 53 & 3.3 & 313 & 1.118 & 2 & & 6 & & 0.0000 \\
\hline Calf death & 89 & 0.3486 & & 0.4797 & & 0 & 1 & & 52 & 0.2 & 307 & 0.42546 & 0 & & 1 & & 0.1456 \\
\hline Panel B & \multicolumn{2}{|c|}{$\mathrm{ae}(\mathrm{T})^{\mathrm{a}}$} & \multicolumn{3}{|c|}{$\operatorname{am}(C)^{b}$} & \multicolumn{3}{|c|}{$\operatorname{gua}(T)^{c}$} & \multicolumn{3}{|c|}{ ha $(c)^{d}$} & \multicolumn{2}{|c|}{$\mathrm{lkw}(\mathbf{c})^{\mathrm{e}}$} & & $\mathrm{mn}(\mathrm{T})$ & & Pv (F) \\
\hline Milkharv & 3.7 & 1.127 & 1 & 0.2 & 42 & $3^{\circ}$ & 1.8 & 6 & 1.3 & 0.5 & 26 & 2.30 .8 & 21 & 2.9 & 0.7 & 20 & 0.0000 \\
\hline Calfdeath & 3 & 0.5 & 0.4 & 0.5 & 42 & 0 & 0 & 6 & 0.4 & 0.5 & 26 & 0.2 & 21 & 0.2 & 0.4 & 20 & 0.0434 \\
\hline
\end{tabular}

${ }^{\mathrm{a} a e}=$ Adieyo; ${ }^{\mathrm{b}} \mathrm{am}=$ Amoke; ${ }^{\mathrm{c}}$ gua= Guaeda; ${ }^{\mathrm{d}} \mathrm{ha}=$ Hadushadi; ${ }^{\mathrm{e}} \mathrm{lkw}=$ Laelaykewanit; ${ }^{\mathrm{f}} \mathrm{mn}=$ Menqerakho

Source: Own survey data analysis, 2016

\subsection{Econometrics estimation of milk production and calf death}

The estimated results of milk harvest measured in terms of litters per cow per day and probability of death of calves below one year old measured in binary value are provided in the Appendix I. Accordingly, the coefficient of interest participation in appendix I suggests that stall feeding (policy intervention) positively and significantly increases milk harvest by almost 1.3 liters per cow per day given that the estimate is statistically significant at 5\%. Our research output is consistent with the previous researches (Ngeno, 2018; Woldegebriel et al., 2017; Kipkoech, 2014; Zimbe, 2012). But; it's against (Meul et al., 2012). The same table (3.2) displayed that linear probability model estimates suggest that the treatment has no significant effect on death of new-born calves but using a $2 \mathrm{~S} \mathrm{IV}$ estimator correctly presents the true impact of the policy and the probability of death for the newly born calves is significantly lower in the policy villages than in the control villages. Thus, newly born calves in the stall-feeding village have $68 \%$ probability of surviving than calves in the open grazing village at its marginal effect. It's the same finding with the previous outcomes (Moran, 2011). The amount of milk consumed by the new calf before actual milking significantly affects milk harvest negatively and cows which lives in a permanent stable (local shell) provides 0.413 littersmore milk 
than cows living without shell (open). In fact, our result is similar to the previous works (Kipkoech, 2014; Zimbe, 2012).

Milk harvest also seems very conditional on season implying that milking cows can give 3.2 litters when milked in autumn, 1.4 litters in summer, and 0.8 litters in spring relative to the winter season. Opposite to the previous findings (Adane et al., 2015; Nalunkuuma, 2013; Nganga et al., 2010), male households seem to harvest 0.239 litters more milk than female-headed households. Household's age, religious education, and low economic status (receive aid) reduce milk harvest significantly. The result is opposite to (Adane et al, 2015; Nganga et al., 2010). Whereas, consistent with (Sultana et al., 2016; Majiwa et al., 2010).The estimation of variables in the calf death model also shows that calves from breed cows have less chance of dying than calves from a local cow (Ojango et al., 2016; Nalunkuuma, 2013). Brewery residue consumption appears to play in reducing a calf death. However, milking frequency and distance to water source significantly increase the probability of calf death in the study area (Kipkoech, 2014; Zimbe, 2012; Moran, 2011). Domestic cow milk yield declined by 0.19 litters as compared to the crossbreed cows and is reliable too (Ngeno, 2018; Ojango et al., 2016; cited in Duguma and Janssens, 2016; Adane et al., 2015; Nalunkuuma, 2013; Tegegne et al., 2013).

Furthermore, the estimation used 2S IV named school distance measured in walking minutes for students and a binary variable membership of Tabia council. Distance to school is supposed to have a negative effect on participation in stall feeding and council membership with a positive impact on participation. Indeed, our findings are as equal as the last outcomes (Ngeno, 2018; Adane et al., 2015; Kipkoech, 2014). Numbers of family size and herd size of small-scale household's positively affected milk yield of stall feeding adopters' (Ngeno, 2018; Adane et al., 2015). However, it's contrary to what is in him (Nalunkuuma, 2013).

For short view, table 3 as part of appendix II presents the summary of the impact of stall feeding on milk yield and calf numbers of calf deaths is almost equal.

\section{Table 3: Impact of stall feeding on milk harvest and calf death}

\begin{tabular}{lcccc}
\hline Estimates & Variable & OLS/LPM & IV-2SLS & IVTREG \\
\hline Milk Harves & Hhpart & 0.0311 & $1.259^{* *}$ & $1.2539^{* * * *}$ \\
Calf Death & Hhpart & -0.241 & $-0.677^{* * *}$ & $-0.4189^{* *}$ \\
\hline
\end{tabular}

Source: Own estimate, 2016. *shows significance at $10 \%$, ** at $5 \%$ and $* * *$ at $1 \%$ level

In the milk model, the estimation used two instrumental variables (in appendix II) named school distance measured in walking minutes for students and a binary variable membership of Tabia council. Distance to school is supposed to have a negative effect on participation in SF and council membership with a positive impact on participation. Referring to Appendix II, the endogeneity test with WU-Hausman F-test at a p-value of 0.04 supports the use of IV estimation to be efficient and consistent, Moreover, the candidate instruments have also passed the over identification requirement at a Sargan p-value of 0.73 indicating that the first assumption that instruments should not be correlated to the error term in the structural model is fulfilled.

Since application of instrument approach requires the instrument to meet the second assumption that the instrument is correlated to the endogenous variable (participation in this case), the F statistics from the first stage estimation ensures the strength of the instruments with its $F$ statistics value of 42.04 greater than the rule of thumb, 10. Following the same procedure and explanation, the instruments in the calf death model estimation prove to pass endogeneity test at a p-value of 0.0096 , over identifications test at a p-value of 0.93 and F- statistics of 26 for relevance test. 
Though the main objective of this paper is to provide an IV-2SLS estimate of SF impact, it is of some interest to compare the IV-2SLS results with those from IV treatment regression. Because one of the drawbacks of the IV method is that during weak instrumentation, the danger of instrument is much higher than the diseases of endogeneity that exist under the original regressions leading to higher standard errors and lower t-statistics leading to accepting the null hypothesis when it is not actually accepted and making the impact of the policy unrepresentative. To address this concern, an alternative strategy is to estimate the equation using IV treatment regression approach which is a proper regressionapproach when selection is made either based on observable covariates or unobservable characteristics such as personal ability, awareness, commitment, level of information and the propensity to accept changes (Blundell and Monica, 2000).

Table 4: Estimate results from IV treatment regression approach (robustness)

\begin{tabular}{|c|c|c|c|c|c|c|c|}
\hline \multirow{2}{*}{ Estimates } & \multicolumn{2}{|c|}{ ATE } & \multicolumn{2}{|c|}{ ATET } & \multicolumn{2}{|c|}{ ATENT } & \multirow{2}{*}{$\begin{array}{c}\begin{array}{c}\text { Significance } \\
\text { level }\end{array} \\
\end{array}$} \\
\hline & $\mathbf{P}>|\mathbf{z}|$ & $\operatorname{Obs}(\mathrm{To})$ & $\mathbf{P}>|\mathbf{z}|$ & $\operatorname{Obs}(\mathrm{T})$ & $\mathbf{P}>|\mathbf{z}|$ & $\operatorname{Obs}(\mathrm{C})$ & \\
\hline \multicolumn{8}{|l|}{ Panel A } \\
\hline Milkest1 & $\begin{array}{c}1.2539 \\
0.000\end{array}$ & 141 & $\begin{array}{c}1.4343 \\
0.000\end{array}$ & 52 & $\begin{array}{c}1.1485 \\
0.000\end{array}$ & 89 & At $5 \%$ \\
\hline Calfdest1 & $\begin{array}{c}-0.4189 \\
0.045 \\
\end{array}$ & 141 & $\begin{array}{c}-0.4418 \\
0.016 \\
\end{array}$ & 52 & $\begin{array}{c}-0.4056 \\
0.086\end{array}$ & 89 & At $10 \%$ \\
\hline
\end{tabular}

Source: Own estimate, 2016

Note: ATE=Average Treatment Effect, ATET=Average Treatment Effect on Treated and ATENT=Average Treatment Effect on non-Treated

Panel A in the above table ensures that the ATE of milk harvest and calf death is almost quite comparable not only in sign, significance but also in magnitude with the previous results approving the consistency of the estimation approach.

\section{CONCLUSION}

Stall feeding adopters' milk productivity per cow per day is 1.3 litters higher than non-adopters. Similarly, the newly born calves in the stall feeding villages have $68 \%$ probability of surviving than calves in the open grazing village. In fact, economic status, cow type, education, market distance, extension service, gender, milking frequency, and cows live in shell matters. In the end, stall feeding has registered remarkable multiple economic impacts in the study area in a short period of time.

\footnotetext{
Funding: This study received no specific financial support.

Competing Interests: The authors declared that they have no conflict of interests.

Contributors/Acknowledgement: All authors participated equally in designing and estimation of current research.

Views and opinions expressed in this study are the views and opinions of the authors, Asian Journal of Agriculture and Rural Development shall not be responsible or answerable for any loss, damage or liability etc. caused in relation to/arising out of the use of the content.
}

\section{References}

Adane, Z., Shiferaw, K., \& Gebremedhin, B. (2015). Sources of the technical inefficiency of smallholder farmers in milk production in Ethiopia. LIVES Working Paper 3. Nairobi, Kenya: ILRI.

Behnke, R., \& Metaferia, F. (2011). The contribution of livestock to the Ethiopian economy-PartII. IGAD Livestock Policy Initiative. IGAD LPI Working Paper No. 02-11. Djibouti: IGAD. Available from http://www.igad-lpi.org/publication.

Blundell, R., \& Monica, C. (2000). Evaluation methods for non-experimental data. Fiscal Studies, 21(4), 427-468. view at Google scholar / view at publisher 
BoFED, (2010). Growth and transformation plan from 2010/11-2014/15. Mekelle, Tigrai, Ethiopia. view at Google scholar

De Cao, E., van den Berg, M.M., Tile, C.Y., \& Wondwosen, T. (2013). The effects of zero grazing in Ethiopia. In: Proceedings of the CSAE conference 2013: economic development in Africa, pp. 1-15. view at Google scholar

Duguma, B., \& Janssens, G. P. J. (2016). Assessment of feed resources, feeding practices and coping strategies to feed scarcity by smallholder urban dairy producers in Jimma town, Ethiopia. Springer Plus, 5(1), 717. view at Google scholar / view at publisher

FAO. (2018). Food and agriculture organization of the United Nations. Gateway to dairy production and products. http://www.fao.org/dairy-production-products/production/dairy...en.

Heckman, J. (1997). Instrumental variables: a study of implicit behavioral assumptions used in making program evaluations. Journal of Human Resources, 32(3), 441-462. view at Google scholar / view at publisher

Kipkoech, L. D. (2014). Factors affecting the economic importance of zero grazing on dairy farmers in Kericho county Kenya. BA Essay, Reg no: A87/3535/2010. Presented to Pambo Kennedy Otieno.

Majiwa, E., Kavoi, M., \& Murage, H. (2010). Smallholder dairying in Kenya; The assessment of the technical efficiency using the stochastic production frontier model. Economic Journal, 14(2), 3-16. view at Google scholar

Meul, M., Van Passel, S., Fremaut, D., \& Haesaert, G. (2012). Higher sustainability performance of intensive grazing versus zero-grazing dairy systems. Agronomy for Sustainable Development, 32(3), 629-638. view at Google scholar / view at publisher

Moran, J. B. (2011). Factors affecting high mortality rates of dairy replacement calves and heifers in the tropics and strategies for their reduction. Asian-Australasian Journal of Animal Sciences, 24(9), 1318-1328. view at Google scholar / view at publisher

Nalunkuuma, J. (2013). Analysis of farmers' adoption of zero grazing and knowledge of cattle reproductive parameters in Western Kenya. Master of Science. Jomo Kenyatta University of Agriculture and Technology (JKUAT).

Negassa, A., Rashid, S., Gebremedhin, B., \& Kennedy, A. (2012). Livestock production and marketing in food and agriculture in Ethiopia. Progress and Policy Challenges. Paul Dorosh and Shahidur Rashid Editors. PENN Press.

Nganga, S., Kungu, J., Deridder, N., \& Herrero, M. (2010). Profit efficiency among Kenyan smallholder milk producers, a case study of Meru South District. African Journal of Agricultural Research, 5(4), 332-337. view at Google scholar / view at publisher

Ngeno, V. (2018). Impact of dairy hubs on smallholder welfare: empirical evidence from Kenya. Agricultural and Food Economics, 6(1), 1-12. view at Google scholar / view at publisher

Ojango, J. M. K., Wasike, C. B., Enahoro, D. K., \& Okeyo, A. M. (2016). Dairy production systems and the adoption of genetic and breeding technologies in Tanzania, Kenya, India and Nicaragua. Animal Genetic Resources/Resources, 59, 81-95. view at Google scholar / view at publisher

Stapleton, J. (2018). Research spurs increase in milk production. Productivity, and Sale in Ethiopia.

Sultana, M. N., Uddin, M. M., \& Peters, K. J. (2016). Socio-economic determinants of milk production in Bangladesh: an implication on on-farm water use. Livestock Research for Rural Development, 28(1), 7-8. view at Google scholar

Tegegne, A., Gebremedhin, B., Hoekstra, D., Belay, B., \& Mekasha, Y. (2013). Smallholder dairy production and marketing systems in Ethiopia: IPMS experiences and opportunities for market-oriented development. IPMS Working Paper 31. ILRI, Nairobi, Kenya. view at Google scholar / view at publisher

Woldegebriel, D., Udo, H., Viets, T., Harst, E., \& Potting, J. (2017). Environmental impact of milk production across an intensification gradient in Ethiopia. Livestock Science, 206, 28-36. view at Google scholar / view at publisher 
Zimbe, J. J. (2012). Socio-economic impact of dairy cattle zeroes grazing production system on the livelihoods of the rural poor in Uganda (A case study of Sironko dairy heifer project). Msc Thesis. 2006/HD17/6758, Makerere University, Kampala, Uganda. view at Google scholar

\section{Appendix}

Appendix I: Estimation of milk harvest and probability of calf death

\begin{tabular}{|c|c|c|c|c|}
\hline Variables & $\begin{array}{l}\text { (OLS) } \\
\text { Milkharv }\end{array}$ & $\begin{array}{l}\text { (IV-2SLS) } \\
\text { Milkharv }\end{array}$ & $\begin{array}{l}(\text { LPM }) \\
\text { Calfdeath }\end{array}$ & $\begin{array}{l}\text { (IV-2SLS) } \\
\text { Calfdeath }\end{array}$ \\
\hline Hhpart(household participation=1) & $\begin{array}{l}0.0311 \\
(0.119)\end{array}$ & $\begin{array}{l}1.259 * * \\
(0.624)\end{array}$ & $\begin{array}{l}-0.241 \\
(0.213)\end{array}$ & $\begin{array}{c}\mathrm{C} \\
(0.235)\end{array}$ \\
\hline Cowtype $($ local cow $=0 \&$ bred cow $=1)$ & $\begin{array}{l}-0.187 * * \\
(0.0787)\end{array}$ & $\begin{array}{l}0.0738 \\
(0.145)\end{array}$ & $\begin{array}{l}-0.167 \\
(0.123)\end{array}$ & $\begin{array}{c}-0.260 * * \\
(0.111)\end{array}$ \\
\hline Cowage(age of milking cow in years) & $\begin{array}{c}0.0575 \\
(0.0668)\end{array}$ & $\begin{array}{l}-0.0276 \\
(0.0865)\end{array}$ & $\begin{array}{l}0.0485 \\
(0.112)\end{array}$ & $\begin{array}{c}0.0786 \\
(0.0956)\end{array}$ \\
\hline $\begin{array}{l}\text { Breresidu(if cow uses brewery } \\
\text { residue }=1 \text { ) }\end{array}$ & $\begin{array}{l}-0.124 \\
(0.106)\end{array}$ & $\begin{array}{l}-0.0206 \\
(0.104)\end{array}$ & $\begin{array}{l}-0.213^{*} \\
(0.112)\end{array}$ & $\begin{array}{l}-0.250 * * \\
(0.0997)\end{array}$ \\
\hline $\begin{array}{l}\text { Foodshare(cow food share in 50- } \\
\text { killosack) }\end{array}$ & $\begin{array}{c}0.0196 \\
(0.0438)\end{array}$ & $\begin{array}{c}0.0715 \\
(0.0610)\end{array}$ & $\begin{array}{c}0.0785 \\
(0.0900)\end{array}$ & $\begin{array}{c}0.0601 \\
(0.0809)\end{array}$ \\
\hline $\begin{array}{l}\text { Equalfed(if cow is equally fed with } \\
o x=1 \text { ) }\end{array}$ & $\begin{array}{l}-0.139 \\
(0.139)\end{array}$ & $\begin{array}{l}0.0330 \\
(0.187)\end{array}$ & $\begin{array}{l}-0.190 \\
(0.151)\end{array}$ & $\begin{array}{l}-0.251^{*} \\
(0.130)\end{array}$ \\
\hline $\begin{array}{l}\text { Calfmilk(length of milking minutes by } \\
\text { calf) }\end{array}$ & $\begin{array}{l}-0.0005 \\
(0.0258)\end{array}$ & $\begin{array}{l}-0.0890^{*} \\
(0.0538)\end{array}$ & $\begin{array}{c}0.0625 \\
(0.0430)\end{array}$ & $\begin{array}{c}0.0939 * * * \\
(0.0358)\end{array}$ \\
\hline $\begin{array}{l}\text { milkfreq(daily milking frequency in } \\
\text { rounds) }\end{array}$ & $\begin{array}{c}0.139 \\
(0.154)\end{array}$ & $\begin{array}{r}-0.0233 \\
(0.164)\end{array}$ & $\begin{array}{l}0.258^{*} \\
(0.144)\end{array}$ & $\begin{array}{c}0.315^{* *} \\
(0.126)\end{array}$ \\
\hline $\begin{array}{l}\text { livingstab(if cow lives in shed=1, open } \\
\text { stable }=0 \text { ) }\end{array}$ & $\begin{array}{c}0.148 \\
(0.100)\end{array}$ & $\begin{array}{c}0.413 * * \\
(0.173)\end{array}$ & $\begin{array}{l}0.0628 \\
(0.129)\end{array}$ & $\begin{array}{r}-0.0312 \\
(0.114)\end{array}$ \\
\hline $\begin{array}{l}\text { eelgrass (if cow eat elephant grass }=1 \text { if } \\
\text { not } 0 \text { ) }\end{array}$ & $\begin{array}{c}-0.247 * * \\
(0.110)\end{array}$ & $\begin{array}{c}-0.354 * * \\
(0.171)\end{array}$ & $\begin{array}{c}0.119 \\
(0.195)\end{array}$ & $\begin{array}{c}0.157 \\
(0.160)\end{array}$ \\
\hline $\begin{array}{l}\text { sessespa(if cow uses sespania sespan=1 } \\
\text { if not } 0 \text { ) }\end{array}$ & $\begin{array}{l}-0.0261 \\
(0.0496)\end{array}$ & $\begin{array}{c}-0.136 \\
(0.0934)\end{array}$ & $\begin{array}{l}-0.153 \\
(0.122)\end{array}$ & $\begin{array}{l}-0.114 \\
(0.107)\end{array}$ \\
\hline $\begin{array}{l}\text { consfreq(consultancy frequency in round } \\
\text { in a year) }\end{array}$ & $\begin{array}{l}-0.0118 \\
(0.0188)\end{array}$ & $\begin{array}{l}0.00108 \\
(0.0188)\end{array}$ & $\begin{array}{c}0.0153 \\
(0.0262)\end{array}$ & $\begin{array}{c}0.0107 \\
(0.0232)\end{array}$ \\
\hline $\begin{array}{l}\text { waterdis(distance to water for cattle in } \\
\text { minutes) }\end{array}$ & $\begin{array}{c}0.0004 \\
(0.0017)\end{array}$ & $\begin{array}{c}0.0006 \\
(0.0022)\end{array}$ & $\begin{array}{r}0.0079 * * \\
(0.0037)\end{array}$ & $\begin{array}{r}0.0078 * * \\
(0.0034)\end{array}$ \\
\hline $\begin{array}{l}\text { sumseasn(if cow is milked at summer }=1 \\
\text { if not } 0 \text { ) }\end{array}$ & $\begin{array}{c}2.030 * * * \\
(0.115)\end{array}$ & $\begin{array}{c}1.421 * * * \\
(0.320)\end{array}$ & $\begin{array}{c}0.178 \\
(0.178)\end{array}$ & $\begin{array}{c}0.394 * * \\
(0.196)\end{array}$ \\
\hline $\begin{array}{l}\text { autseasn(if cow is milked at auto men=1 } \\
\text { if not } 0 \text { ) }\end{array}$ & $\begin{array}{l}3.728 * * * \\
(0.275)\end{array}$ & $\begin{array}{l}3.170^{* * *} \\
(0.322)\end{array}$ & $\begin{array}{c}0.293 \\
(0.266)\end{array}$ & $\begin{array}{l}0.491^{*} \\
(0.273)\end{array}$ \\
\hline $\begin{array}{l}\text { sprseasn(if cow is milked at spring }=1 \text { if } \\
\text { not } 0 \text { ) }\end{array}$ & $\begin{array}{l}1.179 * * * \\
(0.0804)\end{array}$ & $\begin{array}{c}0.772 * * * \\
(0.203)\end{array}$ & $\begin{array}{l}0.0917 \\
(0.153)\end{array}$ & $\begin{array}{l}0.236^{*} \\
(0.143)\end{array}$ \\
\hline calfsex $(1=$ female and $0=$ male $)$ & $\begin{array}{c}0.0740 \\
(0.0557)\end{array}$ & $\begin{array}{c}0.0780 \\
(0.0633)\end{array}$ & $\begin{array}{c}0.0919 \\
(0.0895)\end{array}$ & $\begin{array}{c}0.0904 \\
(0.0800)\end{array}$ \\
\hline $\begin{array}{l}\text { typepart(interaction of cow type \& } \\
\text { treatment ) }\end{array}$ & $\begin{array}{c}0.124 \\
(0.163)\end{array}$ & $\begin{array}{l}-0.425 \\
(0.301)\end{array}$ & $\begin{array}{l}0.0231 \\
(0.180)\end{array}$ & $\begin{array}{c}0.218 \\
(0.178)\end{array}$ \\
\hline vdindex(village development indicators) & $\begin{array}{l}0.00679 \\
(0.0432)\end{array}$ & $\begin{array}{c}-0.103 \\
(0.0695)\end{array}$ & $\begin{array}{c}0.0961 \\
(0.0623)\end{array}$ & $\begin{array}{l}0.135^{* *} \\
(0.0578)\end{array}$ \\
\hline hhsex (household sex: male $=1$ if not 0 ) & $\begin{array}{c}0.343 * * * \\
(0.126)\end{array}$ & $\begin{array}{l}0.239^{*} \\
(0.133)\end{array}$ & $\begin{array}{l}-0.195 \\
(0.143)\end{array}$ & $\begin{array}{l}-0.158 \\
(0.136)\end{array}$ \\
\hline hhage(age of household) & $\begin{array}{r}-0.0594 * \\
(0.0308) \\
\end{array}$ & $\begin{array}{r}-0.0612^{*} \\
(0.0334) \\
\end{array}$ & $\begin{array}{c}-0.0255 \\
(0.0345) \\
\end{array}$ & $\begin{array}{c}-0.0249 \\
(0.0304)\end{array}$ \\
\hline
\end{tabular}




\begin{tabular}{lcccc}
\hline hhsize(the size of the household in unit) & -0.00860 & 0.0144 & -0.00181 & -0.00997 \\
divorce(if husband live with his wife=1 & $(0.0170)$ & $(0.0245)$ & $(0.0289)$ & $(0.0262)$ \\
if not 0) & $(0.168)$ & -0.0927 & 0.175 & 0.130 \\
hhledu(if literacy education=1 if not 0) & -0.0521 & 0.0142 & 0.138 & 0.114 \\
hwspr (if hh has water spring in his plot & $(0.0925)$ & $(0.111)$ & $(0.106)$ & $(0.0971)$ \\
= 1 ) & -0.0945 & -0.166 & 0.185 & $0.211^{*}$ \\
hhtlu(total hh animal holding in TLU) & $-0.0033)$ & $(0.104)$ & $(0.135)$ & $(0.121)$ \\
markdis(market distance from home in & $(0.0045)$ & 0.0010 & $-0.0129 *$ & $-0.0145^{* *}$ \\
minuets) & 0.0015 & -0.0011 & 0.0025 & 0.0034 \\
excendis(FTC distance from home in & $(0.0014)$ & $(0.0018)$ & $(0.0024)$ & $(0.0022)$ \\
minutes) & $(0.0019$ & 0.0002 & -0.00377 & -0.0045 \\
cage2(milking cow age square) & -0.00530 & $(0.0022)$ & $(0.0032)$ & $(0.0027)$ \\
& $(0.0042)$ & $(0.0050)$ & -0.0005 & -0.0022 \\
hage2(hh age square) & $0.0005^{*}$ & $0.0005 *$ & $0.0066)$ & $(0.0055)$ \\
hhredu(if hh has religious education=1 if & $(0.0002)$ & $(0.0003)$ & $(0.0003)$ & 0.0002 \\
not 0) & $(0.0794$ & $-0.140 *$ & 0.0133 & 0.0349 \\
hheclass(hh economic class: if hh get & $-0.241^{* *}$ & $(0.0780)$ & $(0.0904)$ & $(0.0834)$ \\
aid=1) & $(0.104)$ & $(0.130)$ & -0.163 & -0.158 \\
Constant & $2.490^{* *}$ & $2.997 * * *$ & -0.463 & -0.643 \\
Observations & $(1.022)$ & $(1.118)$ & $(1.024)$ & $(0.918)$ \\
R-squared & 141 & 141 & 141 & 141 \\
\hline
\end{tabular}

Source: Own Estimate, 2016. Robust standard errors in parentheses $* * * p<0.01, * * p<0.05, * p<0.1$

$*$ shows significance at 10-percent level, $* *$ at 5-percent level and *** at 1 -percent level

\section{Appendix II: Tests of instrumental variables (IV)}

\begin{tabular}{|c|c|c|c|c|}
\hline Model & Instruments & Endogenity test & Over identification test & Weakness test \\
\hline Milke & $\mathrm{n}$ & $\begin{array}{l}\mathrm{F}(\mathrm{p} \text {-value }) \\
(0.0400)\end{array}$ & $\begin{array}{c}\text { Chi2(p-value }) \\
(0.7264)\end{array}$ & $\begin{array}{c}\mathrm{R}^{2} \text { or F-statistics } \\
(0.83,42.04)\end{array}$ \\
\hline Calfdest $3^{b}$ & schodisschograzr & $(0.0096)$ & $(0.9301)$ & $(0.9174,26.984)$ \\
\hline
\end{tabular}

Source: Own estimate, 2016

${ }^{\mathrm{a}}$ MILKEST=milk estimation, and CalfDest $3^{\mathrm{b}}=$ calf death estimation model 